Social Sciences on Contemporary Turkey

6 | 2007

THEMATIC ISSUE

III-literate Knowledge

\title{
Illiteracy, ill-literacy and literacy among Western Armenians: En route from the Near East to the West, from the 1950s until today
}

Hervé Georgelin

\section{(2) OpenEdition \\ 1 Journals}

\section{Electronic version}

URL: http://journals.openedition.org/ejts/1313

DOI: $10.4000 /$ ejts.1313

ISSN: $1773-0546$

Publisher

EJTS

\section{Electronic reference}

Hervé Georgelin, « Illiteracy, ill-literacy and literacy among Western Armenians: En route from the Near East to the West, from the 1950s until today », European Journal of Turkish Studies [Online], 6 | 2007, Online since 27 December 2007, connection on 16 February 2020. URL : http:// journals.openedition.org/ejts/1313 ; DOI : 10.4000/ejts.1313 


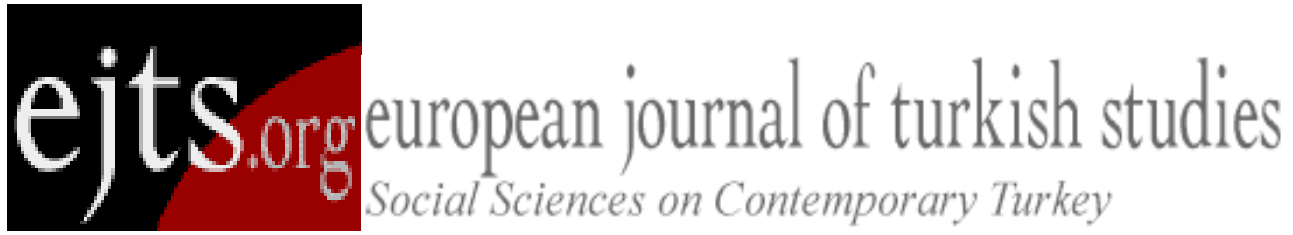

Citation: Georgelin, Hervé (2007) 'Illiteracy, ill-literacy and literacy among Western Armenians: En route from the Near East to the West, from the 1950s until today', European Journal of Turkish Studies, Thematic Issue $N^{\circ} 6$, III-literate Knowledge, URL : http://www.eits.org/document1313.html

To quote a passage, use paragraph (§).

\title{
Illiteracy, ill-literacy and literacy among Western Armenians: En route from the Near East to the West, from the 1950s until today
}

Hervé Georgelin

\begin{abstract}
Based on observations of a post-Ottoman Armenian family and their network of relatives and friends made over more than fifteen years, this article scrutinizes the switch from an almost exclusively oral to a predominantly written world of perception, expression, and communication. Far from being solely an impediment to social life in the Western world, social and cognitive skills acquired in the Ottoman popular culture and inherited by the family's new generations proved helpful in new places and new settings. Though changes occur over generations, these are relatively slow and are still in progress. The common Ottoman Armenian heritage, including the Armenian language still link together a group of relatives scattered over three continents, be it in a frail way.
\end{abstract}


Citation: Georgelin, Hervé (2007) 'Illiteracy, ill-literacy and literacy among Western Armenians: En route from the Near East to the West, from the 1950s until today', European Journal of Turkish Studies, Thematic Issue $\mathrm{N}^{\circ} 6 \mid$ III-literate Knowledge, URL : http://www.ejts.org/document1313.html

To quote a passage, use paragraph (§)

This text is dedicated to Siroun M. and Garabed K. ${ }^{1}$. In many ways, it is theirs.

Was ill-literacy an impediment to Armenians of the Ottoman Empire, and does it continue to be one to their descendants today? III-literacy might not mean social ineffectiveness, an idea that is not so self-evident for a researcher having been educated in the modern French system, where writing is the standard of knowledge. I intend to present in the following pages some aspects of the variation among illiteracy, ill-literacy and literacy from one generation to the next of one Western Armenian family, encompassing five generations, originally from Urfa and Muş in today's Turkey. From these places, one adult and a few children established themselves in 1916-1919 in Aleppo, and in turn created their own families whose descendents I happened to meet ${ }^{2}$. I have known some of the people to be mentioned for over fifteen years. I have spent a great deal of time with them and have (an experience seminal enough) visited Aleppo and Beirut with them twice. Sharing time with the third generation, wherever on the globe they may be, means constantly evoking Aleppo in the 1950s. I consider therefore my knowledge of their family life to be intimate, quite necessary a prerequisite of which one could be unfortunately oblivious.

[2] What do I mean by 'ill-literacy'? I apply this term to most members of generation three. Certainly they had access to formal education. They are not utterly puzzled by written texts. Still some of them cannot decipher at once a sign on the street without intending to do it. Still some are not really able to write a private letter in any language. Even if the skills to write simple texts and read (mostly Armenian) literary texts had once been acquired, for most of them the habit is gone. This may not necessarily differentiate people from the Near East from Western Europeans. Obviously though, generation four has a different experience with written words. They cannot ignore a sign on the

1 The Christian names used in this article are the real ones. The family names are indicated by an initial only, in order to protect their privacy. The M. and K. families are my Armenian families of reference. Sharing much time with them taught me that their ways and ideas were shared and vigorous in post-Ottoman situations, be they situated in the Near East, the Paris area or Greater Los Angeles. There is no cold indifference in my descriptions and analysis, what else is to be expected if one participate according to the ethnographical canons in one's observation?

2 The most comprehensive and innovative works about what happened from 1915 onwards to the Ottoman Armenians are today Kévorkian (2007) and Dündar (2006). 
Citation: Georgelin, Hervé (2007) 'Illiteracy, ill-literacy and literacy among Western Armenians: En route from the Near East to the West, from the 1950s until today', European Journal of Turkish Studies, Thematic Issue $\mathrm{N}^{\circ} 6 \mid$ III-literate Knowledge, URL : http://www.ejts.org/document1313.html

To quote a passage, use paragraph (§)

street, even on purpose. The deciphering is immediate. All of them are able to write a letter at least in one language, and in many cases in two, given their trained bilingualism, including Armenian.

[3] In addition to memories of my various repeated contacts, I have asked direct questions about their family history to some of the people I am closest to. These interviews took place in the first semester 2006. I used semi-open questions first and they started talking. According to their educational level, I explained more or less precisely my intent behind the questions. No one refused to answer and everyone understood I was interested in 'education', reading, and languages, a topic quite popular among the members of the family themselves, so that our conversations had nothing odd for them. I could get information about five generations of Armenians, the first one being born in the Ottoman Empire in the last decades of the $19^{\text {th }}$ century. This case study harmonizes with Thompson's concept of oral history, shedding some light on a discreet history ${ }^{3}$. As a further reassurance process, I could find similarities with many testimonies in the Western Armenian literature ${ }^{4}$, whose partial reflection on reality is a modus of establishing credibility (Corbin 2000: 4647). The chosen family is a random sample of people. I would not pretend they are representative of every single phenomenon among Western Armenians scattered over the planet. Their individuality is as telling as that of Alain Corbin's Louis-François Pinagot (Corbin 1998). Most probably none will leave much written testimony about themselves. The random choice of the family may provide some insights from a particular view into situations analogously shared by others. My experience is that the social and linguistic knowledge I acquired in their company, illiterate, ill-literate, or literate as they may be, was highly functional in further contacts with other Armenians living elsewhere in the world.

\section{Traumatic history, illiterate background and social statuses}

[4] This text is mainly based on the third generation's information, the oldest I closely know. But I have also met Loussine mama belonging to the second generation, while the first generation remembered did not make the journey until Aleppo with the exception of Loussia (G1 - K), who died in 1957. That is so early that I had no chance to meet her.

3 'Reality is complex and many-sided and it is a primary merit of oral history that, to a much greater extent than other sources, it allows the original multiplicity of stand-points to be recreated' (Thompson 2000: 6); 'History becomes, to put it simply, more democratic' (Thompson 2000: 9).

${ }^{4}$ Data about Armenian literature are to be found in Kurkjian (2003; 2004). 
Citation: Georgelin, Hervé (2007) 'Illiteracy, ill-literacy and literacy among Western Armenians: En route from the Near East to the West, from the 1950s until today', European Journal of Turkish Studies, Thematic Issue $\mathrm{N}^{\circ} 6$ | III-literate Knowledge, URL : http://www.ejts.org/document1313.html

To quote a passage, use paragraph (§)

Table 1: Armenian family interacted with

\begin{tabular}{|c|c|c|c|c|}
\hline \multirow{3}{*}{$\begin{array}{l}\text { Generation } \\
\text { one } \\
\text { Generation } \\
\text { two }\end{array}$} & \multicolumn{2}{|l|}{ Family M./U. } & \multirow{2}{*}{\multicolumn{2}{|c|}{$\begin{array}{l}\text { Family K./9. } \\
\text { - Loussia, Krikor's mother }\end{array}$}} \\
\hline & \multirow{2}{*}{\begin{tabular}{|l}
$?$ \\
- Loussine mama \\
married with Alexan
\end{tabular}} & \multirow{2}{*}{$\begin{array}{l}\text { - Sirayn, Alexan's and } \\
\text { Missaq's mother } \\
\text { - Missaq, Alexan's } \\
\text { brother, } \\
\text { married with Loussia } \\
\end{array}$} & & \\
\hline & & & $\begin{array}{l}\text { - Rebeqqa, } \\
\text { married with } \\
\text { Krikor }\end{array}$ & $\begin{array}{l}\text { - Khanım } \\
\text { (Rebeqqa's } \\
\text { sister), } \\
\text { married with } \\
\text { arabacı } \\
\text { Mossig }\end{array}$ \\
\hline $\begin{array}{l}\text { Generation } \\
\text { three }\end{array}$ & $\begin{array}{l}\text { - Hagop } \\
\text { - Takouhi } \\
\text { - Siroun } \\
\text { - Ara }\end{array}$ & & $\begin{array}{l}\text { - Jacques } \\
\text { - Garabed }\end{array}$ & \\
\hline $\begin{array}{l}\text { Generation } \\
\text { four }\end{array}$ & $\begin{array}{l}\text { a. Hagop's children: } \\
\text { Soma, } \\
\text { Dikran } \\
\text { b. Takouhi's children: } \\
\text { Zvart, Hagop, Jirayr }\end{array}$ & c. Siroun's and Garabe & daughter: $\mathrm{Me}$ & \\
\hline $\begin{array}{l}\text { Generation } \\
\text { five }\end{array}$ & $\begin{array}{l}\text { a. Zvart's children: } \\
\text { Makrid, Talar, Aleqo } \\
\text { b. Hagop's sons: Dikran, } \\
\text { Mher } \\
\text { c. Jirayr's daughters: Rita, } \\
\text { Loussine }\end{array}$ & Melanie's children: Cha & Mannig & \\
\hline
\end{tabular}

Legend: In bold, the people I personally met

[5] My very first observation was that education and literacy have always been a major topic of discussion, since I had met the family in Heidelberg, Germany, and during my stays in Aleppo, Syria. For instance, Garabed (G3 - K) recalled his mother, Rebeqqa (G2 - K), promoting her two sons' formal education and insisting on sending them to the Armenian Catholic school of the Mekhitarist monks so that they had a chance to learn proper Armenian and French ${ }^{5}$. Jacques (G3 $\mathrm{K})$, his brother, was offered a violin and sent to music classes. Jacques earned a French baccalauréat, i.e. a high school diploma, in newly independent Syria, and after a stop-over in Venice, managed to get a modest scholarship and study architecture at Leuven, Belgium. On the other side

5 In 1700, the Mekhitarist Catholic order was founded by Abbot Mekhitar, originally from Sebastia/Sivas (1676-1749). The order's activity largely contributed to a cultural and hence national reawakening (2unponip [Zartonq]) of the Armenians everywhere in the world. For an old-fashioned vita see Inglisian (1929). 
Citation: Georgelin, Hervé (2007) 'Illiteracy, ill-literacy and literacy among Western Armenians: En route from the Near East to the West, from the 1950s until today', European Journal of Turkish Studies, Thematic Issue $\mathrm{N}^{\circ} 6 \mid$ III-literate Knowledge, URL : http://www.ejts.org/document1313.html

To quote a passage, use paragraph (§)

of the family tree, Siroun (G3 - M) still takes much pride in having attended the Aleppo College, the former American College at Antep, until her freshman year. Despite various levels of formal educational, the three of them have various but rather limited practices with written documents, especially books or newspapers. Siroun is the only one who almost regularly reads a newspaper, the Armenian daily printed in Paris, Haratch ${ }^{6}$, and seldom some books, in Armenian or English, for her own pleasure?.

[6] In retrospect, whether they knew or not how to read and write constitutes a distinction, a normative, though not ultimate one for the informants themselves. Siroun (G3 - M) speaks about her father, Alexan, as someone who knew 'how to write and read, who had a nice handwriting, [though] no patience to write'8. Alexan went to the Armenian primary school in Muş. But it is significant that his daughter praises in retrospect the beauty of his handwriting ${ }^{9}$, something her mother, Alexan's widow, Loussine mama (G2-M) would do about her own son's, Hagop's (G3 - M), too. Alexan's granddaughter (Melanie, G4 -K) insists that he could decipher the Latin alphabet but was not able to make sense out of it, as she once witnessed when he visited her in Germany. The rule in this generation (G2) was that people were closed to illiteracy or completely illiterate. This was particularly true in the case of women. Women's formal education underwent a process of modernization within the Armenian community as in all other population groups of the Ottoman Empire, with the classical lack of synchronicity between males and females (Rowe 2003: 17-32).

[7] Loussia (G1 - K), the eldest person to reach Aleppo in the family, was illiterate. The reality is acknowledged without shame when speaking to me, today. I remember close friends of the family, feeling compelled to explain why their mother was illiterate, even during my second visit in Aleppo,

\footnotetext{
${ }^{6}$ Bunnuz or Haratch was founded in Paris in 1925 by Schavarch Missakian, a Constantinople Armenian intellectual. At that time the daily was close to the Armenian Revolutionary Federation and gained full independence afterwards. It is operated today by Schavarch's daughter, Arpik Missakian. I have maintained the orthography used by these persons to write their names with the Latin alphabet.

${ }^{7}$ I mean by seldom one or two books as a maximum reading every year and that neither as a norm, nor as a habit but simply as a possibility - I don't survey the family's integration in a consumption market of Armenian cultural goods, if such a market exists, but their reading practises.

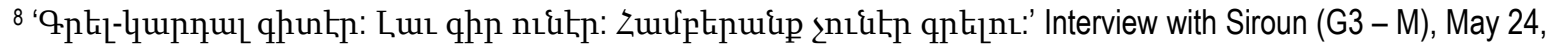
2006.

${ }_{9}^{9}$ The standard appraisal is formulated that way: 'Һр qhpp uunqphunh ulku k:' ['his handwriting is pearl-like'].
} 
Citation: Georgelin, Hervé (2007) 'Illiteracy, ill-literacy and literacy among Western Armenians: En route from the Near East to the West, from the 1950s until today', European Journal of Turkish Studies, Thematic Issue $\mathrm{N}^{\circ} 6 \mid$ III-literate Knowledge, URL : http://www.ejts.org/document1313.html

To quote a passage, use paragraph (§)

while I already was part of the group, to some extent, and fluent in Armenian ${ }^{10}$. Beside the first unease felt by descendants, they can (and maybe even feel compelled to) give very good reasons why their ancestors would have preferred to know how to read and write. Armenians being Christians, their religion refers to a holy scripture. Though there is no obligation of personal reading, it is or was something considered desirable by many. We have to mention in this frame that Protestant missionaries influenced the standards of Armenian culture, especially in Syrian or Lebanese exile, but already in Urfa (Kieser 2007). The other side of the family, the M. branch, was close to the Danish missionary, Karen Jeppe who devoted her adult life to relief work among Armenians first in Urfa and then in Aleppo (Tcholaqian 2001). Alexan (G2 - M) was even his official adopted son, together with his brother Missaq ${ }^{11}$. According to the protestant ethic of personally relating to the Scripture, Alexan's wife Loussine mama used to go to Bible readings and had a Bible close to her bed. It was her only regular reading as far as I am informed, one of the very few books one would have noticed in her spartan apartment in Aleppo, when she already was an old lady. Generally speaking, the Holy Scripture enjoyed considerable cultural fame among Armenians at the beginning of the $20^{\text {th }}$ century in Aleppo. Loussia, the other great grandmother on the K. side ( $G 1$ - K), would have liked to read the Bible, as she was actively involved with the Armenian Apostolic Church ${ }^{12}$. There is neither shame nor cynicism about former illiteracy among my main informants.

[8] But soon after the rather classical praise of formal knowledge, when asked for more details about the personalities of the illiterate people, informants would sketch rich and strong personalities that could be naively perceived as quite unexpected. We are thus introduced in retrospect with people who possessed other skills than reading and writing, which certainly were of much relevance, be it in Ottoman Armenian settlements or in post-Ottoman Syria. Loussia (G1 - K) appears to have had a steadfast personality, holding her family together after their catastrophic

\footnotetext{
10 Mrs. B.'s mother was illiterate. This was 'confessed' at a dinner in Aleppo. I am afraid that my status as a fair-haired, educated 'European' may have deceived them about my own family history, in which such occurrences are not seldom at least on my father's side: hence the unpleasantness of this confession. The B.s were formerly a prominent family in Aleppo. Mr. B. used to be one of the most renowned tailors in Syria. He was involved in community life, had excellent connections with the Syrian political and social elite. He is living now in Canada and is well over 80 years of age.

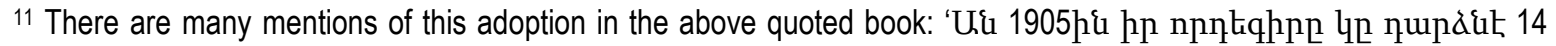
unuptiquif Uhuupp nı l'unsit hp pnl:' ['She adopted 14-year-old Missaq in 1905 and took him at her place']. (Tcholaqian 2001: 19). Missaq and his wife Loussia are on a photograph together with Miss Karen Jeppe (Tcholaqian 2001: 20).

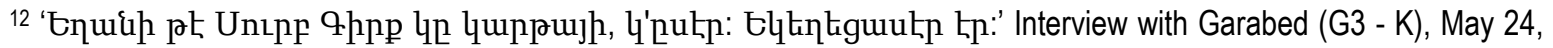
2006.
} 
Citation: Georgelin, Hervé (2007) 'Illiteracy, ill-literacy and literacy among Western Armenians: En route from the Near East to the West, from the 1950s until today', European Journal of Turkish Studies, Thematic Issue $\mathrm{N}^{\circ} 6 \mid$ III-literate Knowledge, URL : http://www.ejts.org/document1313.html

To quote a passage, use paragraph (§)

arrival in Aleppo. She looked after her three sons who were surviving with her: Hagop, Krikor, and Yepran. When Hagop died, Loussia compelled the widowed daughter-in-law (huppu) to marry the youngest son, the hars' former younger brother-in-law, so that her grandson, Kevork, who already had been named after her own husband, his grandfather on the father-side, remained within the family, under her control and protection. She succeeded. Garabed (G3-K), a grandson of hers, said about his grandmother: 'Loussia was a strong woman. Ancient women were like this'13. Loussia used to live together with her second son Krikor, and had a say in this latter's family life. The other hars, Rebeqqa, had to adjust to her authoritarian ways. Rebeqqa's son, Garabed, adds about his mother and his grandmother's relationship: 'With Rebeqqa, there were the mother-in-law-bride kind of problems. My mother, who was seventeen when she married, respected her [Loussia]. You had to respect your mother-in-law (as a woman). That was the principle'14.

[9] The social status evidenced by the authority they possessed was rooted in certain skills. In outmost destitution, between 1916 and 1918, Loussia knew how to choose herbs near Aleppo for her sons to eat. She was in charge of cooking when things came to some state of normalcy. She was renowned as a talented cook ${ }^{15}$. Her former social role as a married woman in Suruç, close to Urfa, was actually this one, which she could transfer to the Syrian shelter. In Suruç, she had to cook for the customers of her husband who came to their home to have their horses treated, possibly shoed, since her husband was a baytar, as one of their grandsons remembered in Turkish, as if the Armenian word would have been too artificial ${ }^{16}$. Loussia's empowering status was underlined by her habit of smoking -quite odd for a woman, but not unheard of for a mature and post-menopausal one, though ${ }^{17}$-, which was financed by her own son Krikor ${ }^{18}$. More than a personal habit, I see in this smoking a way of positing oneself as an important person, beyond social regulations valid for women on the marital market and submitted to men's control.

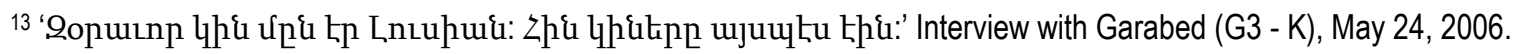

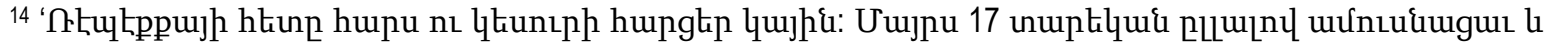

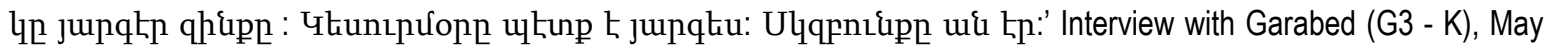
24, 2006.

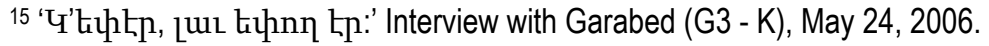

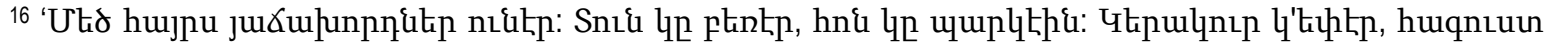

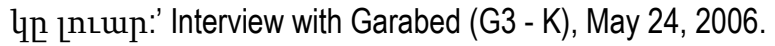

17 The anthropologist Martine Hovanessian has own private recollections of older Armenian women of the first refugee generation gathering to play cards, smoke and talk together.

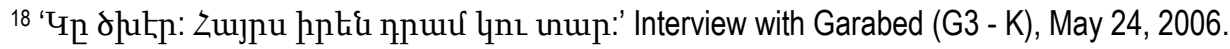


Citation: Georgelin, Hervé (2007) 'Illiteracy, ill-literacy and literacy among Western Armenians: En route from the Near East to the West, from the 1950s until today', European Journal of Turkish Studies, Thematic Issue $\mathrm{N}^{\circ} 6 \mid$ III-literate Knowledge, URL : http://www.ejts.org/document1313.html

To quote a passage, use paragraph (§)

[10] It is a well-known, but for some disconcerting, phenomenon that formal education and even literacy are not a prerequisite for social success and importance [Table 2]. Armenian literature provides us with a validation of such an analysis. Antranig Dzarouguian (1912, Gürün, close to Sivas - 1990, Paris) describes Mihran Effendi in Aleppo, an older male that appeared to him in his own young years as follows: 'He was a splendid man. Corpulent, voluminous, tall. Especially when he was wearing his fez, he seemed to me like a moving tower. And despite his heavy mass, astonishingly supple and present-minded. He didn't know how to read or write. With an inborn sharp intelligence, he was gifted with a unique spirit and a special talent for entrepreneurship' (Dzarouguian 1980: 39). As far as I have observed, such personalities are present in following generations of the real family I know, even if those have reached a higher level of formal education, theoretically above illiteracy. Their skills are also exportable and may prove efficient in societies renowned for their literate character.

Table 2: Armenian Family and Formal Educational Level

\begin{tabular}{|c|c|c|c|}
\hline & Family M./U. & Family K./9. & Literacy \\
\hline $\begin{array}{l}\text { Generation one: } \\
\text { Born in today's } \\
\text { Turkey } \\
\text { Arrival in Aleppo: } \\
\text { genocidal } \\
\text { deportation }\end{array}$ & $\begin{array}{l}\text { - Sirayn, Alexandre's mother } \\
\text { - ? (Loussi did not remember her } \\
\text { own family) }\end{array}$ & $\begin{array}{l}\text { - Kevork } † \text { and Loussia } † \\
- \text { ? (Rebekka arrived alone in } \\
\text { Aleppo with her elder sister. } \\
\text { Her younger sister was } \\
\text { abandoned in Mardin) }\end{array}$ & |lliteracy? \\
\hline $\begin{array}{l}\text { Generation two: } \\
\text { Born in today's } \\
\text { Turkey, before } \\
1915 \\
\text { Arrival in Aleppo } \\
\text { as children or } \\
\text { youngsters after } \\
\text { the genocidal } \\
\text { deportation }\end{array}$ & $\begin{array}{l}\text { - Alexan } \dagger \\
\text { - Loussi mama: Six months } \\
\text { Catholic school in Aleppo while } \\
\text { engaged as a precondition to her } \\
\text { wedding }\end{array}$ & $\begin{array}{l}\text { - Krikor } \dagger \text { : one year at the } \\
\text { Armenian school in Urfa } \\
\\
\text { - Rebekka } \dagger \text { : Alphabetized in a } \\
\text { Protestant orphanage in } \\
\text { Aleppo }\end{array}$ & \begin{tabular}{|l} 
Illiteracy \\
or ill-literacy
\end{tabular} \\
\hline $\begin{array}{l}\text { Generation three: } \\
\text { Born in Aleppo, } \\
\text { Syria, from the late } \\
\text { 1920's onward } \\
\text { under French } \\
\text { protectorate } \\
\text { All but one } \\
\text { emiarated to the }\end{array}$ & $\begin{array}{l}\text { - Hagop } \\
\text { - Takouhi (still in Aleppo) } \\
\text { - Siroun } \\
\text { - Ara }\end{array}$ & $\begin{array}{l}\text { - Jacques } \\
\text { - Garabed }\end{array}$ & $\begin{array}{l}\text { Primary, } \\
\text { secondary, } \\
\text { or even } \\
\text { university } \\
\text { education }\end{array}$ \\
\hline
\end{tabular}


Citation: Georgelin, Hervé (2007) 'Illiteracy, ill-literacy and literacy among Western Armenians: En route from the Near East to the West, from the 1950s until today', European Journal of Turkish Studies, Thematic Issue $\mathrm{N}^{\circ} 6 \mid$ III-literate Knowledge, URL : http://www.ejts.org/document1313.html

To quote a passage, use paragraph (§)

\begin{tabular}{|c|c|c|c|}
\hline & Family M./U. & Family K./৭. & Literacy \\
\hline \multicolumn{4}{|l|}{ 'West' } \\
\hline $\begin{array}{l}\text { Generation four: } \\
\text { Born from the late } \\
\text { 50s onward, } \\
\text { living in the 'West' }\end{array}$ & $\begin{array}{l}\text { - Soma, Dikran } \\
\text { - Zvart, Hagop (still in Aleppo), } \\
\text { - Jirayr (still in Aleppo) } \\
\text { - Melanie } \\
\varnothing\end{array}$ & $\begin{array}{l}\text { - Melanie } \\
\varnothing\end{array}$ & $\begin{array}{l}\text { University } \\
\text { education } \\
\text { but one } \\
\text { person }\end{array}$ \\
\hline $\begin{array}{l}\text { Generation five: } \\
\text { Scattered between } \\
\text { the East Coast, } \\
\text { France and } \\
\text { Aleppo } \\
\text { Little contact with } \\
\text { one another }\end{array}$ & $\begin{array}{l}\varnothing \\
\text { - Markrid, Talar, Aleqo } \\
\text { - Two sons (still in Aleppo) } \\
\text { - Two daughters (still in Aleppo) } \\
\text { - Chahé - Mannig }\end{array}$ & & $\begin{array}{l}\text { According to } \\
\text { the age and } \\
\text { place of } \\
\text { residence: } \\
\text { at least } \\
\text { secondary } \\
\text { education } \\
\text { planned by } \\
\text { the parents }\end{array}$ \\
\hline
\end{tabular}

[11] Garabed's relative social success proves that a limited functional literacy may be enough even in a society in the West, Germany, in which written texts are a daily given. Garabed (G3 - K) is at ease with German administrative regulations. He can find his way in the administrative jargon. $\mathrm{He}$ even managed to go through the naturalization process in Germany in a culturally if not economically unwelcoming period, the 1970s. It was made clear from the start to the immigré family, that they had no right to become German citizens but that they were simply granted the favour of applying for the German citizenship. They obtained German passports in 1978. There was only a one digit number of people naturalized that year in Heidelberg, as every renewal of Melanie's passport (G4-K) recalls, since she has to prove and reprove each time that she was indeed naturalized.

\section{Collectively investing in education}

[12] Access to formal higher education was granted to very few people in generation three, the first one to be more or less in a powerful economic situation and in a relatively stable political context. In both branches of the family tree, only one person could make it to university. The project was not that of an individual, but a proclaimed ambition by the parents, accepted by the siblings and deliberately supported by the whole group if need be. This attitude challenged mechanistic approaches of social reproduction within the educational framework, even if its effects were limited in 
Citation: Georgelin, Hervé (2007) 'Illiteracy, ill-literacy and literacy among Western Armenians: En route from the Near East to the West, from the 1950s until today', European Journal of Turkish Studies, Thematic Issue $\mathrm{N}^{\circ} 6 \mid$ III-literate Knowledge, URL : http://www.ejts.org/document1313.html

To quote a passage, use paragraph (§)

numbers and certainly in time. Hagop (G3 - M) went to the United States in 1950 and managed to get higher education as an aeronautic engineer. According to his own daughter, Soma (G4 - M), he remained however a simple person with 'limited ambition'. His main aim was normalcy and absence of trouble in daily life. And he succeeded in reaching it. I remember him as an older man, reading newspapers in English and Armenian and having a library. He was a unique case in his generation. Soma would compare her father with Jacques (G3 - K), a comparison that I would not have dared to make, given the aura of Hagop's social success in the US.

[13] Jacques (G3 - K) was predestined by his mother to further studying, because she felt he would not make it in the world of business and had to acquire special qualifications as a protection, as Garabed reported ${ }^{19}$. Her early passing compelled him to interrupt his education after his baccalauréat in 1950 and work for the Compagnie des wagons-lits in Syria ${ }^{20}$. After saving some money, he finished his baccalauréat and by connections of the Mekhitarist order, he went first to Venice. He had also applied for a scholarship in Leuven, which he finally obtained21. There was no single doubt for his brother, Garabed (G3 - K), that he would put his energy at the service of his brother's educational success. Jacques was the one who was older and was closer to the aim (the French baccalauréat) and whose further success was likely. Bacheliers at that time were a tiny minority in France itself, and once one obtained a university education, expectations of social and economic stability were well-founded. Having a French baccalauréat was a secure passport for social promotion at that time, in the Near East and elsewhere. Due to some former regulations, now no more valid, Jacques was easily naturalized in France, as a citizen of a former French mandatory territory. Though Garabed resented the necessity made for him to go and work as an apprentice at a

19 Interview with Garabed (G3 - K), May 24, 2006.

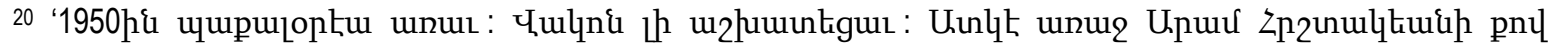

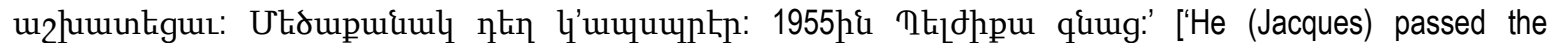
bacccalauréat in 1950. He worked for the wagons-lits. Before that he (even) worked at Aram Hrchdaguian's. He was a chemistry whole-seller. In 1955, he went to Belgium']. Interview with Garabed (G3 - K), May 24, 2006.

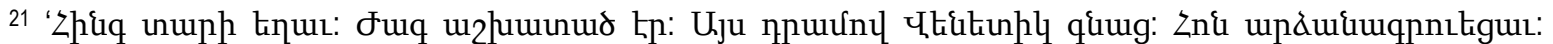

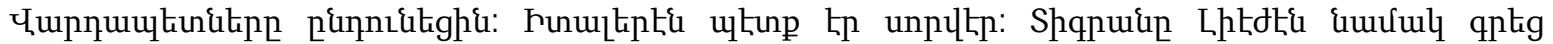
nıuuitinnt: Shqpuifhi pnl quug:' ['Jacques had worked for five years. He could go to Venice with this money, in order to register (as a student) there. The monks had accepted him. He had to learn Italian. Dikran wrote an application letter to (the University of) Liege. He (Jacques) joined Dikran.'] Interview with Garabed (G3 - K), May 24, 2006. 
Citation: Georgelin, Hervé (2007) 'Illiteracy, ill-literacy and literacy among Western Armenians: En route from the Near East to the West, from the 1950s until today', European Journal of Turkish Studies, Thematic Issue $\mathrm{N}^{\circ} 6 \mid$ III-literate Knowledge, URL : http://www.ejts.org/document1313.html

To quote a passage, use paragraph (§)

tailor's shop after their mother's death in 195722, he never regretted having supported, as much as he could, his brother while the latter went on his secondary education and succeeded in migrating to the West in order to study architecture. It was the only possibility for the family as a whole, especially for these two brothers deprived of their mother, to improve their situation or $u n u l \xi \varepsilon_{1} k_{l l} t_{L}$, as one says in Armenian ${ }^{23}$. This dagen yelle/ was not an individual affair but a family business.

[14] The choice of academic focus was not made at random. Studying meant in Aleppo getting a higher social position, particularly a medical doctor, an architect, or any kind of engineer. The same pattern was repeated, when Jirayr (G4 - M) went to Soviet Armenia in order to study pharmacy. His brother, Hagop (G4 - M), partly financed the studies of his brother while working in the United Arab Emirates. His aunt, Siroun (G3 - M) also sent some money to that end. I would expect Hagop (G3 - M) to have participated, too. Jirayr could return, as a married man, to Aleppo, where the economic situation was incomparably better than in post-Soviet Armenia, and establish himself as a pharmacist, a flattering and envied social position. Hagop (G4 - M) himself is an open-minded person, eager for information and discreetly nurturing political ideas relevant to the Armenian context. He cares about his own sons' education. Though the siblings may experience tensions, the investment in the education of the younger brother has not been put into question. Once again, I could not but be astonished by such family-based strategies, in which some individuals overtly 'sacrifice' for others.

[15] Liberal arts were out of the range of coveted careers. There were in fact no possible careers in the Aleppo context, and for most of the heirs of this context. Education is not for free, as one can observe in similar settings, as an Istanbul Armenian novel illustrates in a resentful dialogue between two spouses, written by Zaven Biberian (Istanbul, 1921 - Istanbul, 1984): 'Everyone became rich, we remained as we were. - Don't tell 'everyone'. - You are not a man of work, you are stupid. Supposedly you have studied a lot, what was it good for?' (1984: 229). Though Jacques made his way in the realm of architecture in the West and in a way surpassed all reasonable educational expectations in Aleppo, Garabed never thought of himself as an outcast or of lesser worth than his

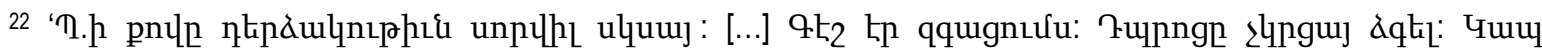

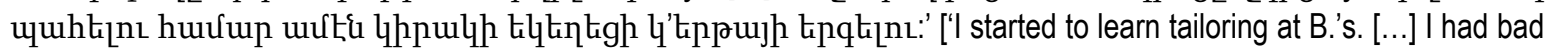
feelings. I could not abandon school. In order to maintain the link, I used to go to sing at the church']. Interview with Garabed (G3 - K), May 24, 2006.

${ }^{23}$ Altından çıkmak is the word-by-word analogous expression. 
Citation: Georgelin, Hervé (2007) 'Illiteracy, ill-literacy and literacy among Western Armenians: En route from the Near East to the West, from the 1950s until today', European Journal of Turkish Studies, Thematic Issue $\mathrm{N}^{\circ} 6 \mid$ III-literate Knowledge, URL : http://www.ejts.org/document1313.html

To quote a passage, use paragraph (§)

brother. In the universe of craftsmen or small business men, a higher educational level has to have a practical impact on one's social status, while Jacques remained a simple man, with limited social contacts within the French society and a very modest way of life in terms of housing, clothing, and leisure-time occupations. I could not notice a real difference in leisure time occupations, especially as far as reading is concerned, between the two brothers, or a sharp difference in their main subjects of private conversation. I have not noticed a disparity of books in one house versus the other. But Jacques was already quite old when I met him, while everyone was praising his brilliant youth including painting and playing the violin, so that my perception may not be entirely correct.

[16] I doubt that there is anything ontologically linked with the Near East in this remark about frozen or dormant literacy. Most people step back from the field of reading and especially literature. Education is seen as a necessary passport to higher social positions. Similar phenomena are to be found elsewhere. There is some resigned or possibly blasé thinking in accepting that studying may not improve one's material situation. If there are traces of resignation in this Armenian family, they do not concern this domain of human life.

\section{Multilingualism and illiteracy or minimal literacy}

[17] What made Garabed (G3 - K) so efficient in these contacts with the administrative, quite unwelcoming German world? He had learned colloquial German fairly well by listening and repeating only (a word perfect repeater) ${ }^{24}$. By doing so, he applied and developed the skills he inherited, already present among Western Armenians in general, especially in context of emigration out of only Armenian-speaking neighbourhoods. His father already had such bewildering skills, as Table 3 easily illustrates (Calvet 1999: 59). His mother insisted on his learning French. Turkish was a given in the neighbourhood where Turkish-speaking Armenians may have been a vast number, since most survivors came originally from Cilicia. Illiteracy or limited formal education is not contradictory to

\footnotetext{
${ }^{24}$ The two languages have very remote links. Basic words may belong to the same Indo-European heritage but this is hardly perceptible for common speakers: $q p k_{l}[\mathrm{krel}]$ and schreiben (to write) may have the same root but it is of little help for a beginner. On the other hand, differences are numerous. While there are three grammatical genders in German, there is none in Armenian (similarly to Turkish). Declension affects substantives in Armenian (like in Turkish) while mostly determinants are concerned in German, etc. Garabed's audio-oral success is not a minimal one, given the little help he has ever received.
} 
Citation: Georgelin, Hervé (2007) 'Illiteracy, ill-literacy and literacy among Western Armenians: En route from the Near East to the West, from the 1950s until today', European Journal of Turkish Studies, Thematic Issue $\mathrm{N}^{\circ} 6$ | III-literate Knowledge, URL : http://www.ejts.org/document1313.html

To quote a passage, use paragraph (§)

multilingualism at all, though this idea is alien to the doxa in France. Once again Armenian literature can validate this assertion. This time, literature transports us to the former imperial capital. 
Citation: Georgelin, Hervé (2007) 'Illiteracy, ill-literacy and literacy among Western Armenians: En route from the Near East to the West, from the 1950s until today', European Journal of Turkish Studies, Thematic Issue N ${ }^{\circ} 6 \mid$ III-literate Knowledge, URL : http://www.ejts.org/document1313.html

To quote a passage, use paragraph (§)

Table 3: Languages across Western Armenian Generations

\begin{tabular}{|c|c|c|}
\hline Generation & Family M./U. & Family K./9. \\
\hline $\begin{array}{l}\text { Generation one } \\
\text { Individual survivors from } \\
\text { the former country }\end{array}$ & $\begin{array}{l}\text { Alexan's mother, Sirayn: } \\
\text { Armenian (Muş dialect?) }\end{array}$ & $\begin{array}{l}\text { Krikor's mother, Loussia: } \\
\text { Armenian (Urfa dialect), some } \\
\text { Turkish only }\end{array}$ \\
\hline \multirow{2}{*}{$\begin{array}{l}\text { Generation two } \\
\text { The Syrian Lands } \\
\text { The two re-founding } \\
\text { couples }\end{array}$} & $\begin{array}{l}\text { Loussi mama: Armenian, } \\
\text { Turkish, some Arabic } \\
\text { married with }\end{array}$ & $\begin{array}{l}\text { Rebeqqa: Armenian (both } \\
\text { standard and Urfa dialect) } \\
\text { married with }\end{array}$ \\
\hline & $\begin{array}{l}\text { Alexandre: Armenian, Turkish, } \\
\text { some Arabic }\end{array}$ & $\begin{array}{l}\text { Krikor: Armenian (both standard } \\
\text { and Urfa dialect), Turkish, } \\
\text { Kurdish, Arabic, French }\end{array}$ \\
\hline \multirow[t]{3}{*}{$\begin{array}{l}\text { Generation three } \\
\text { Migration to the West } \\
\text { (except for Takouhi) }\end{array}$} & $\begin{array}{l}\text { Hagop: Armenian, English, } \\
\text { Turkish, some French, minimal } \\
\text { Arabic? }\end{array}$ & $\begin{array}{l}\text { Jacques: Armenian (both } \\
\text { standard and Urfa dialect), } \\
\text { French, Arabic, Turkish, English, } \\
\text { Italian, some German }\end{array}$ \\
\hline & $\begin{array}{l}\text { Takouhi: Armenian, Turkish, } \\
\text { Arabic }\end{array}$ & $\begin{array}{l}\text { Garabed : Armenian (both } \\
\text { Standard and Urfa dialect), } \\
\text { French, Turkish, Arabic, } \\
\text { German, English }\end{array}$ \\
\hline & $\begin{array}{l}\text { Siroun: Armenian, English, } \\
\text { German, Turkish, Arabic } \\
\text { Ara: Armenian. Turkish. Enalish }\end{array}$ & \\
\hline \multirow[t]{5}{*}{$\begin{array}{l}\text { Generation four } \\
\text { Diaspora Armenians }\end{array}$} & $\begin{array}{l}\text { Zvart: Armenian, Arabic, } \\
\text { English, Turkish }\end{array}$ & $\begin{array}{l}\text { Melanie: Armenian, German, } \\
\text { English, French }\end{array}$ \\
\hline & $\begin{array}{l}\text { Hagop: Armenian, Arabic, some } \\
\text { English }\end{array}$ & \\
\hline & $\begin{array}{l}\text { Jirayr: Armenian (both Western } \\
\text { and Eastern), Arabic }\end{array}$ & \\
\hline & $\begin{array}{l}\text { Soma: Armenian, English, some } \\
\text { Spanish }\end{array}$ & \\
\hline & $\begin{array}{l}\text { Dikran: Armenian, English, } \\
\text { some Spanish }\end{array}$ & \\
\hline \multirow[t]{3}{*}{$\begin{array}{l}\text { Generation five } \\
\text { Diaspora Armenians }\end{array}$} & $\begin{array}{l}\text { Zvart's children: Markrid, Talar, } \\
\text { Aleqo: Armenian, Arabic, } \\
\text { English }\end{array}$ & $\begin{array}{l}\text { Melanie's son and daughter: } \\
\text { Chahé, Mannig: Armenian, } \\
\text { German, French }\end{array}$ \\
\hline & $\begin{array}{l}\text { Hagop's sons: Mher, Dikran: } \\
\text { Armenian, Arabic }\end{array}$ & \\
\hline & $\begin{array}{l}\text { Jirayr's daughters: Rita, Loussi: } \\
\text { Armenian (both Western and } \\
\text { Eastern), Arabic }\end{array}$ & \\
\hline
\end{tabular}

\section{Legend}

In italic: the mother tongue in singular or plural. The mother tongue may be devaluated in the course of life and become only second in proficiency, especially in the generations four and five. Each 
Citation: Georgelin, Hervé (2007) 'Illiteracy, ill-literacy and literacy among Western Armenians: En route from the Near East to the West, from the 1950s until today', European Journal of Turkish Studies, Thematic Issue $\mathrm{N}^{\circ} 6 \mid$ III-literate Knowledge, URL : http://www.ejts.org/document1313.html

To quote a passage, use paragraph (§)

language list is ranged from the best to the lesser known, the graduation being different from individual to individual (more or less so-called perfect multilingualism) From the languages spoken, one can deduce the place of temporary or final residence, even the marital encounters.

For the first generation, hear-say knowledge only is available. From generation three onwards, siblings are considered. The pivotal married couple is Siroun (G3-M) and Garabed (G3-K) whose marriage makes the people considered as a potential family and this table meaningful.

[18] In her autobiographic work, The Gardens of Silihdar, the writer Zabel Yessayian (Istanbul, 1878 - USSR, 1936) described her grandmother, Doudou, born in the second half of the $19^{\text {th }}$ century in Constantinople, in this way: 'She was a proud and sad woman. She did not know how to read nor to write, but she spoke clean Armenian and Turkish with chosen words'. Yessayian's words about her grandmother's Armenian language, a cliché 'clean Armenian' (Uupnıp hujłำtu), are a much enviable assessment, since Yessayian herself was a most refined writer. The combination of illiteracy and multilingualism is a regular phenomenon among Armenians in the Ottoman and post-Ottoman frameworks. It is not exclusively an Armenian talent; other peoples in similar situations of dispersion and trading have produced the same linguistic results. One could suspect greater facility among people with high listening skills and enjoyment of oral expression than among formally educated ones, fixed on the script. Without written support, the development of communicative and rhetorical skills implies training and imitation in social situations where people spontaneously speak with one another and await interaction, something that obviously cannot be recreated easily in fake institutional classrooms, especially in cultural contexts where uniqueness of language and ways of thinking have become the norm. Here I think of my own childhood in a well-off suburb of Paris.

[19] When we speak about the loss of a privileged Ottoman cultural situation, we should recall this natural, at least partial, code-multiplicity, forever gone. Interestingly enough, although Yessayian was not indifferent at all to her Armenian people's political situation as her political involvement may convincingly prove, she did not hesitate to praise her grandmother's Turkish using a more elaborate wording, describing the latter's way of speaking 'with chosen words' [niunhnnц punkinnl], vis-à-vis her assessment of Doudou's Armenian. The one cultural code was not seen as 
Citation: Georgelin, Hervé (2007) 'Illiteracy, ill-literacy and literacy among Western Armenians: En route from the Near East to the West, from the 1950s until today', European Journal of Turkish Studies, Thematic Issue $\mathrm{N}^{\circ} 6 \mid$ III-literate Knowledge, URL : http://www.ejts.org/document1313.html

To quote a passage, use paragraph (§)

antagonistic with the other in the urban context of Istanbul. The possibility of elegance and expressiveness was (nor is by my informants) obviously not denied to the Turkish language.

[20] I can illustrate with a precise observation, what I mean by highly working multilingualism, as not many people can acquire in a classroom setting: On a late summer early afternoon in Aleppo, the Western observer could not walk any more because of the heat. It was necessary for Jacques and Garabed to find a cab. None would stop when finally a private car did. We got in and Jacques said in Arabic where we wanted to go, indicated not the official name of any street almost no one cares about in Aleppo but the name of a major building, in that case a major urban equipment (a railway bridge, the September Bridge, Djesser Tshrin) to give the driver orientation. Astonishingly enough, the driver did not understand them at all. In no time and with no word uttered, both Armenian brothers decrypted the situation: the driver was working illegally in Aleppo and had come from Turkey. They immediately switched language and repeated their instructions in Turkish. The Western observer was struck anew, this time not by the heat, but by the social and cultural competence of the two men who had been living in the West for decades and were still able to react to the culturally complex -at least for the naïve observer- situations of their native town. Needless to say that only a few people with higher education in the West would have been able to adapt instantly the way the two early bilingual brothers did25.

[21] The cultural context of Aleppo in the 1920s until today may have retained or recreated similar traits of cultural plurality according to the Ottoman way. This is something I have observed with the Aleppo Armenian family I have been interacting with for years, even in other places, remote from the former Ottoman Empire. Truly, Garabed (G3 - K) speaks German quite similarly to the craftsmen of the Old City of Heidelberg ${ }^{26}$. Most importantly, he had enough social connections because of the warm welcome and support of his landlord, Herr K., with whom he had close relations until the latter passed away. The German family owning the larger house where he was renting a room and then a flat and later an even larger flat did not consider him as an alien - quite the contrary, in fact. He somehow was adopted by the couple who was about ten years older than he was. These

25 'A precocious bilingual person can transfer his or her skills to any new language' (Dalgalian 2000: 23).

26 There is only one relative pronoun in the Heidelberg dialect: wo, which stands for many other forms in standard German. Genitive constructions are systematically avoided, etc. The prosody is not that of standard German, this is the famous Singsang [singsong] of the area. 
Citation: Georgelin, Hervé (2007) 'Illiteracy, ill-literacy and literacy among Western Armenians: En route from the Near East to the West, from the 1950s until today', European Journal of Turkish Studies, Thematic Issue $\mathrm{N}^{\circ} 6 \mid$ III-literate Knowledge, URL : http://www.ejts.org/document1313.html

To quote a passage, use paragraph (§)

relations were not only a chance, but are partially rational. Garabed's ability as a tailor was esteemed by the landlords and he quickly got customers through the landlady, who was tightly connected with the population of the Old City of Heidelberg. His landlord was a craftsman, and when Garabed established his own business, he could ask for some guidance in administrative steps. He had a partner to speak about common fiscal and judicial matters. After some success, he could go to the same expert bookkeeper and fiscal advisor. Though this did not prevent him from some economic setbacks, he benefited from the general atmosphere of the house in which he was living. Garabed is able to learn by heart administrative formulas that German majors abroad, as myself, never master. If he is not well trained in writing letters, he is able to pick up the right way of formulating things and able to apply them when necessary. We are an unbeatable team when we have to write official letters, while neither of us would be able to do the job alone.

[22] When Garabed has to get in touch with the German administration, he has a low profile attitude, with no overt calculations, just because this is his modus operandi, a way he was well trained for in Syria. The Syrian administration has always the last say with simple people and procedures of appeal are non existent or thoroughly unused. If there is a margin for talks and explanations, the Syrian citizen or the foreign tourist would be suicidal to contest the administrative order. This smooth approach unexpectedly pays back in Germany. Garabed often expresses disagreement with people claiming respect for their acknowledged rights. There are many expressions in German, almost phrasal ones: 'Es ist mein Recht' ['It is my right']; 'Ich habe das Recht' ['I have the right to']; 'Ich will nur meine Rechte' ['I just want my rights']. Garabed finds such attitudes tactless, if not right away morally questionable. Having contacts within German society -quite a seldom resource for immigrants in Germany in the sixties- and having a self-conscious but modest approach of the German local officials made it easier for him to cope with German bureaucracy and written texts. Western societies are not so much within the realm of compulsory script as they may imagine they are.

\section{Domestic practices and topics of conversation}

[23] One resource used, consciously or not, by Garabed and his family in Germany was their proficiency in cooking. Food is a central topic in everyday discussion. This is no Armenian special 
Citation: Georgelin, Hervé (2007) 'Illiteracy, ill-literacy and literacy among Western Armenians: En route from the Near East to the West, from the 1950s until today', European Journal of Turkish Studies, Thematic Issue $\mathrm{N}^{\circ} 6 \mid$ III-literate Knowledge, URL : http://www.ejts.org/document1313.html

To quote a passage, use paragraph (§)

cultural trait; comprehensive works on the anthropological and social importance of food have already been conducted (Dahloul 1983). Cooking and even cuisine are closely linked with the world of orality, and the worlds of illiteracy and orality seem to be fluid, mobile ones. Food is also the material basis for many practices in the new German setting too. Garabed cooked for himself when he was alone in Germany for years, breaking with the stereotypical gender roles of Aleppo. I have never seen him or any other male in the family and circle of relatives cook in Aleppo. I suppose this would be considered an inappropriate occupation ${ }^{27}$. Siroun started cooking immediately when she arrived in Germany, having been spared this domestic chore because of her higher social status due to her education at Aleppo College. After her freshman year, she had to work first as an English teacher at an Armenian school and as bank employee afterwards. As a child, a teenager, and then a young woman, she enjoyed quite a boy-like and hence privileged status within her family28. But getting married implied a change in her habits. She had to activate a dormant know-how to be up to her new duties, which she did29.

[24] The preparation of food expressed the belonging of the Armenian family to a world geographically remote and considered forever lost. It provokes feelings of exoticism for visitors from outside, who are often offered a small Oriental coffee, named Mokka-Kaffee in German. Ironically enough, the Armenian or Greek or Turkish or Arabic coffee knows variations but no frontiers, as the publicist of Armenian background, Jean Kéhayan puts it, automatically activating pieces of his limited Turkish: 'The black coffee smokes in the copper-made jezve and burns the fingers that hold the porcelain-made flidjan. This Turkish coffee, symbol of the Armenian hospitality' (2006: 31). As far as I have experienced, this offer has a positive impact on potential visitors, at least from the 1990s onward, when I started to have social links with the family.

27 'Perpetuating ways of distributing domestic chores cannot only be explained through negative or passive logics: those of the routine effects of socialization, or by combination with asymmetries between gender and professional work [...]. It happens that the perpetuation of a sharp asymmetry in people's involvement in domestic chores is the result of deliberate attitudes putting a point of identity honour at which transgressing habits would challenge the one's status of good mistress of the house and of the other's masculinity' (Guionnet, Neveu 2004: 159). All translations are the author's except otherwise noted.

28 There is something similar to Siroun's culinary status in her Aleppo family to that of Giard (1994a: 214): 'As a child, I refused to accept my mother's invitations to learn cooking with her. I refused this female work, since it never was proposed to my brother. I already had chosen and determined my destiny: one day, I would have a 'real profession'.'

29 'Even if mothers never systematically teach cooking to their daughters, these recall more than their brothers, for they have seen the gestures of everyday and home life' (Chaudron 1983: 162). Though concentrating on Western cases, many remarks can be applied to more remote situations. 
Citation: Georgelin, Hervé (2007) 'Illiteracy, ill-literacy and literacy among Western Armenians: En route from the Near East to the West, from the 1950s until today', European Journal of Turkish Studies, Thematic Issue $\mathrm{N}^{\circ} 6 \mid$ III-literate Knowledge, URL : http://www.ejts.org/document1313.html

To quote a passage, use paragraph (§)

[25] On a symbolic level, the family's Oriental food is plentiful and generously offered to guests and visitors. It combines Anatolian and Arabian meals, and materializes and signifies the belonging of Western Armenians to a region where they are politically not welcome anymore or where they cannot make a decent living in safety. In lack of proper places, they keep or proclaim to keep the food of the places left behind. There is no need for written or loudly spoken political statement in that case. The daily practise more than suffices. Cooking a particular from a particular place in Cilicia (Adana kebabı) or Western Armenia and using such-and-such spice re-assert ever and ever again one's connection to the former territories. This is the Anatolian food, as often dramatically experienced by all Western Armenians visiting Turkey as tourists (Kéhayan 2006: 58).

[26] Investing in food and elaborate cuisine works as a social technique to reinforce the cohesion of the group. It is a way to control males, for instance, warranting their loyalty to their wives and the larger kinship, by offering in exchange a long-lasting pleasure of another nature, a family meal ${ }^{30}$. It keeps women highly busy too, so no one thinks about anything else. Food and cooking hold families together ${ }^{31}$. Fattening up people decreases their seduction to the outside Western world and reduces their potential mobility in a more discreet way than the technique of force-feeding girls in Mauritania, but in quite an efficient manner. A perfect family father would 'quietly sit at home' [hut_op [uunhl] after work and not look for entertainment as younger males are allowed and even expected to do. Garabed's father, Krikor, would disapprove of his sons' presence at his own restaurant, because he would acknowledge the incompatibility of his occupation and his being the head of a family. I have heard similar remarks and have experienced similar social processes in my own Western family. Migration to large cities and radical changes in way of life had reduced these habits to memories in the generation of my parents. Once again, the Near-Eastern nature of this social arrangement is questionable. It is true that it was still efficient, while the Western (i.e. French) counterpart I could compare them with, had already been deeply shaken.

30 'Cooking is first of all the business of women in a family. Does that mean that men are completely absent? Certainly not: let's remind that they are their privileged consumers. They intervene more as 'tasters' than 'practitioners' of cooking: they comment, appreciate or criticize. They can contribute to the composition of a menu, or simply suggest, propose, ask for (women to perform) a dish that they especially like' (Chaudron 1983: 163).

31 'Through the interest and care devoted to preparing meals, in the authorized range of pleasures or the imposed restrictions in that activity, one can read how people relate to their own body and to the Other' (Giard 1994b: 270). 
Citation: Georgelin, Hervé (2007) 'Illiteracy, ill-literacy and literacy among Western Armenians: En route from the Near East to the West, from the 1950s until today', European Journal of Turkish Studies, Thematic Issue $\mathrm{N}^{\circ} 6 \mid$ III-literate Knowledge, URL : http://www.ejts.org/document1313.html

To quote a passage, use paragraph (§)

[27] During a meal, the conversation is centred on what is being eaten, on the way dishes were successfully prepared and what could have been made better. It can evoke strong recollections; for instance, I am regularly reminded of the first time I ate k'bbe labanye, a yogurt soup with tiny köfte and aromatic herbs, a winter delicacy, which took place in September Aleppo, when temperature was above $40^{\circ} \mathrm{C}$. The dish can be attributed to someone absent or a special event. Food, family, and related topics with not much at stake make up the basis of the family conversation. It is a powerful link between people, and I would assume that, when asked, no one is completely naive about what is going on in such circumstances. Though one can think of these practices as boring, they are very efficient and the younger generation cannot easily escape the situation. On the whole, the atmosphere at Garabed's and Siroun's is astonishingly cheerful and does not have much in common with what first generation Armenians have experienced in the Near East or in France ${ }^{32}$. The often renewed pleasure of eating together powerfully contributes to this general atmosphere.

\section{Perception of space}

[28] One of the very first cultural phenomena that astonished me in Siroun's and Garabed's family was their familiarity with spaces nobody would mention in a familiar discussion in my own surroundings ${ }^{33}$. Of course the German space, its geography, especially its tormented parts like the German Democratic Republic or the Eastern territories lost to the Soviet Union and Poland, were for them almost terra incognita. But they had vivid connections with other parts of the planet: Canada, and the east and west coasts of the United States, because some of their relatives and friends had migrated to these parts of the world. Speaking about such places reveals that migration was part of the life project of many young and able Armenians in Syria in the 1950s. Though this may not sound politically correct, the willingly sustained awareness of not being at home in Syria, and therefore in my informants' own logic not completely safe in a non-Christian religious context, reinforced the idea of a necessary further migration. In the same conversations though, Aleppo is the central place of

32 'I have to specify that all second generation Armenians I have interviewed evoked their family past by referring to violent episodes that had been carefully tabooed' (Hovanessian 2007: 166).

${ }^{33}$ This remark does not imply that only group ascription determines one's perception of space. But this is the dimension that I could seize in my observation. Certainly Siroun's Aleppo is not completely that of Garo, because of the gender divide. Certainly a university professor at Aleppo University may know different things about Aleppo that a former tailor in that city back in the fifties. 
Citation: Georgelin, Hervé (2007) 'Illiteracy, ill-literacy and literacy among Western Armenians: En route from the Near East to the West, from the 1950s until today', European Journal of Turkish Studies, Thematic Issue $\mathrm{N}^{\circ} 6 \mid$ III-literate Knowledge, URL : http://www.ejts.org/document1313.html

To quote a passage, use paragraph (§)

reference par excellence. If my informants did not feel at home there, Aleppo has filled up their minds and their home for the rest of their lives ${ }^{34}$. On the same lines, Iran too was no remote place where only unimaginable events might happen, but the original country of many friends and acquaintances. I compared the places regularly spoken about with those that were familiar to my own family: the three French provinces from where the different family branches had come to Paris, and which we used to visit in my childhood, a few neighbouring European countries we had visited or with which my parents happened to be in professional contacts, like Germany for instance. America was remote and something slightly out of reach, even after some travels there, although it was a major place of reference in my informants' discussion and some kind of a natural extension of their familiar space. In comparison, the space evoked in my Western European life appeared very limited. Though the third generation is hardly able to read a geographic map, even those with the highest level of education, and does not have the necessary orientation skills to make their way easily with only a map, they have a vast picture of the world that is organized in quite a different way from what is understood in literate societies ${ }^{35}$.

[29] This observation was often renewed in Aleppo and with people coming from Aleppo visiting the family under scrutiny in Europe. The mere idea of using a street-map while moving around in Paris appeared incredible for many visitors. At the same time, using a map of Aleppo was deemed strange but very practical, since most of the official street and place names in the city are not used by the inhabitants. Cardinal points seem to be a mere formula with hardly any practical meaning (Lynch 1960: 128 sqq). Knowing them in Armenian is almost funny. People seize their space using other means: the red building [Yupukp ${ }_{2} k$ ip], the public garden [zukipuujhi uqupunkq], such-andsuch church (Forty Martyr's church [funzuunz\& Uuiznz $]$ ], the Rum Orthodox St. George church), the Bagdad railway station [Gare de Bagdad], said in Aleppo French in any language spoken, or the September Bridge, one of the few official terms with practical use. The relevant reference marks

34 Possibly until generation four, they remember having been aware of the possible instability of politics and geopolitics in the region, of the relative lack of business opportunity back in the late fifties, and of being prepared for religious and cultural reasons to desire emigration. Still Aleppo may be the only place for generation three, where home-feelings are the most firmly established. 'A good environmental image gives its possessor an important sense of emotional security' (Lynch 1960: 4).

35 'Space divisions like above/underneath, left/right, North/South, East/West, are according to Durkheim [in The Elementary Forms of Religious Life] neither subjective categories of perception nor qualities pertaining to space itself. These distinctions are rather collectively shared attributions' (Schroer 2006: 49) 
Citation: Georgelin, Hervé (2007) 'Illiteracy, ill-literacy and literacy among Western Armenians: En route from the Near East to the West, from the 1950s until today', European Journal of Turkish Studies, Thematic Issue $\mathrm{N}^{\circ} 6 \mid$ III-literate Knowledge, URL : http://www.ejts.org/document1313.html

To quote a passage, use paragraph (§)

within the urban fabrics were not necessarily to be found on a map, a typical foreign item in the Aleppo setting. Reference marks are not even the same for the whole Aleppo population either, as one of my informants experienced it. This person had to drive a taxi for some months before migrating to Northern America. All of a sudden, he had to locate mosques in the city in order to quickly drive his customers around. But he had completely ignored these buildings before, except the most famous. The experienced topography of Aleppo is particular to certain groups. The religious divide is of major relevance in that unwritten or undrawn perception of space. But all groups use analogous mnemonic means based on their specific use of the urban space, quite obviously the Jewish Aleppo, which nowadays remains in the spirit of very few, it is almost gone but probably was functioning in an analogous modus ${ }^{36}$.

Table 4: Mental/conversational geography of Generation three

Places referred to as experienced places or places where relatives are living:

\begin{tabular}{|c|c|c|c|c|c|}
\hline \multicolumn{3}{|c|}{ America / Uuthphluu } & \multirow{3}{*}{$\begin{array}{l}\text { Europe / } \\
\text { Eцрпщи }\end{array}$} & \multirow[t]{3}{*}{ Near East / Unkltkp } & \multirow{3}{*}{\begin{tabular}{|l|} 
Armenian \\
Republic / \\
Zujuuuunu\&
\end{tabular}} \\
\hline USA & & Canada & & & \\
\hline $\begin{array}{l}\text { East } \\
\text { Coast }\end{array}$ & $\begin{array}{l}\text { West } \\
\text { Coast }\end{array}$ & & & & \\
\hline $\begin{array}{l}\text { Worces } \\
\text { ter }\end{array}$ & \multirow[t]{2}{*}{$\begin{array}{l}\text { Los } \\
\text { Angeles } \\
\text { area }\end{array}$} & \multirow[t]{2}{*}{ Toronto } & $\begin{array}{l}\text { Germany / } \\
\text { q.pufuughu } \\
\text { Heidelberg }\end{array}$ & $\begin{array}{l}\text { Syria / Unıphuu } \\
\quad \text { Aleppo / Zulıul }\end{array}$ & \multirow[t]{2}{*}{$\begin{array}{l}\text { Yerevan / } \\
\text { Epluuid }\end{array}$} \\
\hline $\begin{array}{l}\text { Watert } \\
\text { own }\end{array}$ & & & $\begin{array}{l}\text { France / } \\
\text { Dpulquuu } \\
\text { Paris area }\end{array}$ & $\begin{array}{c}\text { Lebanon / Lhpuifuí } \\
\text { Beirut / Thjpnıp }\end{array}$ & \\
\hline
\end{tabular}

Places referred to as friends' places of residence, of origins:

\begin{tabular}{|c|c|c|}
\hline & $\begin{array}{l}\text { Great-Britain / } \\
\text { UiquLhuu } \\
\text { London }\end{array}$ & $\begin{array}{c}\text { Iran / Tupuquuuuuk } \\
\text { Tehran }\end{array}$ \\
\hline & $\begin{array}{l}\text { Greece / } \\
\text { 3nzquuuunus } \\
\text { Salonica / } \\
\text { Utyuukhy }\end{array}$ & $\begin{array}{l}\text { Turkey / Onıpqhuu } \\
\text { Istanbul / TnLu }\end{array}$ \\
\hline
\end{tabular}

Places referred to as the cradle, the original place: 'real' places, constantly evoked:

Aleppo / zultur

36 Jean-Charles Depaule has studied in-depth similar phenomena, with regard to Cairo for instance. See the list of his publications on www.ivry.cnrs.fr/lau/spip.php?article268 (visited on December 12, 2007). 
Citation: Georgelin, Hervé (2007) 'Illiteracy, ill-literacy and literacy among Western Armenians: En route from the Near East to the West, from the 1950s until today', European Journal of Turkish Studies, Thematic Issue $\mathrm{N}^{\circ} 6$ | III-literate Knowledge, URL : http://www.ejts.org/document1313.html To quote a passage, use paragraph (§)

\section{Urfa / nıp\$u \\ Adiyaman / Uunhjuưưu Muş / Unı2}

[30] The importance of places in today's Turkish Republic is one of the most disturbing experiences for an outside observer. My expectations would have been that these places were tabooed, but not at all. There are numerous ways by which Turkey is present at the K.s', not especially with a dramatic connotation, although political discussions may take place too.

[31] The origins of Garabed from Urfa are rhetorically stressed quite often, especially when spices are evoked. People from Urfa $\left[\Omega_{L} \phi q u g h\right]$ are supposed to appreciate spicy food in particular. In Istanbul, I could buy 'very hot pepper from Urfa' [Urfa süper acı biberi] at the Egyptian bazaar, which I brought back for Siroun and Garabed. They were very enthusiastic about my present, as if they were transported to that important place for good at last. In Aleppo, compatriotic associations are still active on the basis of the former places of residence in the Ottoman Empire. Though the generation who really knew the places is no more, their descendents maintain these associations and invest their time in such activities. Urfa is present too through the Armenian dialect once spoken there, which Garabed and Jacques used to speak when together, until Siroun appeared and normalized the language use towards more standard Armenian. Still, sayings by the grandmother, Loussia, are quoted in the original tongue and special words are ironically used ${ }^{37}$. Garabed enjoys repeating that the Urfa dialect was close to classical Armenian [qpupup]. I assumed this is partly true and never argue, to everyone's contentment. Garabed has a strong personality, and though he is aware of the little communicative use of this dialect, he enjoys quoting phrases with no regard to the standard norms. He would also use some dialectal words without noticing ${ }^{38}$, because this is the normal form for him and his brother. Siroun is very proud of her father being originally from Muş [Unı2]. Muş has a special meaning for Armenians with a nationalist background. Its name stands for a tough community, eager to protect oneself and fight nomadic neighbouring populations if need be, despite their inferior legal status as zimmi - i.e. as non-Muslim subjects. Though Alexan was a teenager when he departed from there, Muş is constantly evoked

${ }^{37}$ Like fuulhip for key, while Standard Armenian is Fuirul h.

38 Like $\eta h p n\llcorner\varepsilon$ instead of $\eta h u p h \varepsilon$. 
Citation: Georgelin, Hervé (2007) 'Illiteracy, ill-literacy and literacy among Western Armenians: En route from the Near East to the West, from the 1950s until today', European Journal of Turkish Studies, Thematic Issue $\mathrm{N}^{\circ} 6 \mid$ III-literate Knowledge, URL : http://www.ejts.org/document1313.html

To quote a passage, use paragraph (§)

together with Siroun's father, like a Homeric epithet. She can even specify the name of the village Alexan was from: Msho Avan $\left[\mathrm{U}_{2} \mathrm{n}_{\mathrm{J}} \mathrm{Uluw}_{\mathrm{u}}\right]^{39}$. Asking about the location on a map of these places evokes only discomfort. The former country is known because of the narratives about the abandoned places, of the characteristics attached to the people originally from there, the food that was cooked there, etc. This kind of knowledge has little in common with a geographic map of today's Turkey, but most probably more with the geography experienced on the spot.

[32] Turkey was present in the German setting because of the presence of Turkish Gastarbeiter, the famous guest-workers who were supposed to work in Germany in the sixties and seventies and go back to their home country, which the overwhelming part of them did not. Garabed did not avoid this company. He was happy enough to find some Turkish bakkal, grocery stores, in order to buy unheard-of fruits and vegetables in Germany at that time: aubergine, zucchini, watermelons, etc. He even prefers to buy meat at the Turkish butchers, especially lamb, which is difficult to purchase at German shops. Garabed is able to express himself in Turkish. His fluency is that of an Anatolian peasant with the specific phonetic traits of that Turkish, though he obviously has an Armenian accent, as Turkish friends from Istanbul have told me (possibly with marked snobbism). His capacity however ensures him the sellers' immediate demonstrative consideration. As an old man now, he is immediately granted rhetorical marks of respect. Garabed happened to have colleagues of Turkish origin and had the best relationship with them because of his language knowledge. When asked about the source of his ability, he would simply reply that his Armenian neighbours back in Aleppo, originally from Antep or Maraş, would only speak Turkish, and that as a child he picked up the language while playing. Another version, also heard, is that he re-learned, or sometimes he says learned Turkish while in Germany, which makes the discreet but robust vivacity of the Turkish language among Armenians in Aleppo until today taboo, though the linguistic phenomenon has been reinforced by the attractiveness of Turkish television compared to the dull Syrian state-controlled TVprograms. I witnessed Zvart (G4 - M) answering the phone in Aleppo in Turkish with an older Armenian asking for someone else, though she would never say about herself that she speaks Turkish, which would be accepting that Turkish was a major language in her father's family and would mean acknowledging a lower social status according to educated Armenian standards in Aleppo.

39 Interview with Siroun (G3 - M), May 24, 2006. 
Citation: Georgelin, Hervé (2007) 'Illiteracy, ill-literacy and literacy among Western Armenians: En route from the Near East to the West, from the 1950s until today', European Journal of Turkish Studies, Thematic Issue $\mathrm{N}^{\circ} 6 \mid$ III-literate Knowledge, URL : http://www.ejts.org/document1313.html

To quote a passage, use paragraph (§)

[33] One of Garabed's colleagues was especially close to him, despite his wife's devout Muslim religiousness. They even went together on vacations in Turkey. The colleague in question, Selim, very lately acknowledged that one of his grandfathers was an Armenian who converted, in order to escape 'misfortune' in 1915. But above all, the sameness of occupation (both are tailors), their shared language, and some similarities in their status as immigrants in Germany made the two men closer than one may have expected, despite the religious divide, emphasized by the German social structures ${ }^{40}$. As incredible as it may sound, Siroun, daughter of enthusiastic tashnag (Armenian Revolutionary Federation) sympathizers, would acknowledge or proclaim -is the doubt only mine? that she feels at home in Turkey. In such statements, she refers to places where the former Armenian presence was minimal and went without leaving much traces ${ }^{41}$. This familiarity with Turks is not popular among kin, especially those living in countries with not so sizeable Turkish populations: the US, Canada, and Syria. Even Siroun's and Garabed's daughter, who doesn't speak Turkish, doesn't feel the same closeness to the problematic and so similar Other. But Garabed goes his own way, followed by Siroun, and doesn't care about puufpuuuisp, that is dedikodu, the same habit of social regulation in the former Ottoman society despite its various names: gossip.

[34] The term Armenia was seldom used and only described the Soviet Republic, and then the Independent Republic of Armenia. Armenia Armenians do not enjoy the best reputation among people from Aleppo of that generation. The Soviet work ethics and the lack of efficiency of the economic system were incomprehensible for 1960s Armenians living in Syria or Lebanon - societies with minimal state intervention, where individuals, be it in the frame of families and to a lesser extent in that of the community, have to rely on themselves to achieve anything. Still, contemporary Armenia is the 'fatherland' [Lujpkifhp], which if not flattering in most cases, is the only one that can be referred to as such. The term Western Armenia, in reference to the six Ottoman provinces with a large, if not majority Armenian population, was unusual, even misunderstood until generation four introduced it. I have never heard the word $E_{R} h h p$ [land or country] used to refer to these places,

40 In this synthetic essay, Todd (1994) contrasts the assimilationist and universalist treatment of migrants in a French context, that he considers as still efficient despite alarming clichés and episodic spectacular difficulties, whatever the religious group considered, and the particularist differentialist surroundings in Germany, accounting for the ghettoization of some Gastarbeiter and more dramatically of their descendents.

${ }^{41}$ Siroun brought back from a seaside sojourn in Antalya a few years ago an unexpected antique (?) metallic box with an Armenian family name in Armenian and Christian symbols graved on it. We all saw in this item the confirming materialization of her feelings towards the so special place she had visited. 
Citation: Georgelin, Hervé (2007) 'Illiteracy, ill-literacy and literacy among Western Armenians: En route from the Near East to the West, from the 1950s until today', European Journal of Turkish Studies, Thematic Issue $\mathrm{N}^{\circ} 6 \mid$ III-literate Knowledge, URL : http://www.ejts.org/document1313.html

To quote a passage, use paragraph (§)

though it was a political populist slogan at the beginning of the twentieth century in Istanbul, especially: 2tuyh knlhp [Towards the country!] to encourage younger urban people to get acquainted with a space referred to as a national one. This usage seems to have maintained itself in France among émigré Armenians before WWII. $E_{P} l_{h} p$ meant the former lands forcibly abandoned. There is usually no collective term to embrace any territory. Instead, there are numerous names of former places. As in Turkey today, the name of the principle town of the smaller region gives its name to the inhabitants of the whole region, which can be first identified by the main centre and may then specify secondarily the smaller place from which they come.

[35] The term Diaspora [ $U_{\zeta \not h L n p]}$ is of limited spontaneous use. Once again, the term is more familiar to generation four, even if understood by generation three. Imagining the situation of being dispersed is certainly not easy, even more so if one considers that the influence of some organizations in Aleppo, like the Armenian Revolutionary Federation for family M. and some scouts' groups for family $\mathrm{K}$., have emphasized in a preach-like manner the territoriality of Armenia in vague but vivid tones. The difficulty is reinforced by the fluidity of the dispersion. Once displaced, a population is likely to be ready for further moves. The Armenian dispersion is no exception. The perception of some advantages to this situation may have been reinforced in the last twenty years since air travel costs became affordable, telephone calls became cheaper, and internet connections made instant communication possible. Generation four can, at least at some moments, abolish the dispersion and remain in touch or feel as if they remained in touch despite the distances. Melanie who is living in Paris and Soma who resides in Orange County (southern France) regularly exchange e-mails. Zvart and Siroun often telephone with one another. Loussine mama, who was living in Aleppo, was regularly called on the phone by Siroun from Germany and Hagop from California in her last years.

[36] The discourse about the dispersion is very ambiguous. On the one hand, it is seen as a concrete possibility of getting more material resources and some perspectives for one's children. On the other hand, it is associated with a feeling of loss and decline in the quality of collective life (Dufoix 2003; Bruneau et al. 2007). This is especially true for generation three, who did not get access at an equivalent level with formal cultured life in their countries of residence. Aleppo, the disgraced Arab city from which one had to escape, remains simultaneously the referential point of normal collective 
Citation: Georgelin, Hervé (2007) 'Illiteracy, ill-literacy and literacy among Western Armenians: En route from the Near East to the West, from the 1950s until today', European Journal of Turkish Studies, Thematic Issue $\mathrm{N}^{\circ} 6 \mid$ III-literate Knowledge, URL : http://www.ejts.org/document1313.html

To quote a passage, use paragraph (§)

life. Generation four still has some emotional attachment to Aleppo and the older characters they knew or had heard of, like Loussine mama. She is even a character for the children of generation five in Aleppo and elsewhere. But there is no familiarity and no desire for longer stays for most who have grown up in the West. The phenomenon is reinforced in the case of Turkey. Generation four feels foreign and diffusely threatened when in Turkey. Among the six members of generation four, only one has ever been to Turkey. Family members still living in Aleppo were tempted but were not granted a tourist visa when they applied for one years ago. In a way, generation four is at home in the familiar dispersion. The loss may be interpreted, rightly or not, as liberation of social control and narrowmindedness. But generation four has other means to cope with the situation than generation three. In this particular family, because of the belated migration to the West and the emphasis laid by generation three on acquiring the language, Armenian still functions as a powerful link across continents and oceans and among generations. Most French Armenians do not share that experience.

\section{Limited literacy and transmitting a language in the Western Dispersion}

[37] I consider it necessary to address now the special, and not so special, linguistic status of the language in which all I have mentioned until now is taking place. That is the status of the Armenian language, specifically its Western standard - Batı Ermenice, as spoken in ancient Ottoman lands and in the Western Diaspora, as opposed to Eastern Armenian, the official language of the Republic of Armenia and the large Armenian community in Iran. This distinction makes the very use of 'Western' and 'Eastern' more perilous than ever in this article, since Western Armenians and their language were located until the 1910s in the 'East' as once defined by Western Europeans! Garabed's and Siroun's daughter, Melanie (G4 - K) was a bilingual child, as some early recordings attest, already before she went to school. Her familiarity with the landlord's family, to the extent that the landlady was chosen as her godmother and the Lutheran church accepted as the normal one, enabled her to learn local German with the local pronunciation ${ }^{42}$, while Armenian was spoken in her

\footnotetext{
42 Melanie thinks that her relative ease with foreign languages may partly be a consequence of her own 'diglossy' in German, combining the Heidelberg dialect with the Hochdeutsch norm. Her intuition may be correlated with systematic observations in Hagège (1996: 207).
} 
Citation: Georgelin, Hervé (2007) 'Illiteracy, ill-literacy and literacy among Western Armenians: En route from the Near East to the West, from the 1950s until today', European Journal of Turkish Studies, Thematic Issue $\mathrm{N}^{\circ} 6$ | III-literate Knowledge, URL : http://www.ejts.org/document1313.html

To quote a passage, use paragraph (§)

own restricted family. Her Armenian pronunciation at that time was similar to that of any child in Beirut or Aleppo, as an audio tape recorded in her childhood amply and amusingly demonstrates.

[38] Garabed and Siroun had no sophisticated theory about language transmission at home ${ }^{43}$. Their common language was Armenian, and they did not consider abandoning it when they had their only child. Their strong foreign languages - French for Garabed, and English for Siroun - did not allow them to adjust intimately to their surroundings. They had experienced multilingualism in Aleppo and did not fear it, neither for themselves nor for their own daughter [Table 3]. Only women from some region of the former country may have been unilingual. The norm and not the exception was multilingualism.

[39] Their attitude on this matter is not very popular in the West, especially in the US or in France, where larger Armenian communities make their home, in spite of much lip service in recent years ${ }^{44}$. Garabed and Siroun were often challenged by friends in their choice. Some male Armenian students had established themselves in the vicinity and had married German women who had not learned Armenian. These marriages overtly prevented the husbands from transmitting the Armenian language to their children. Melanie was the exception that disturbed some comfortable Europecentrist patterns ${ }^{45}$. Speaking Armenian at home was not synonymous with failure at school or in the broader German society. The fact that Melanie's parents were partly working outside of German society on an American military base, made it even less realistic for them to switch to German at home. Since Melanie had no language problem when entering the school system, languages were

43 'In many families, languages come and go with no apparent criterion, 'anyhow'. In fact, even where disorder seems to prevail, even when the agents in the given situation are not aware of it, an unspoken convention network regulates interactions. For instance: the one who starts talking decides on the language to be used. Or: if one speaks about school or holidays, or makes reproaches or confidences (?), the one language or the other is used. Theorists speak in that case of topic- and register-driven switches. After some thorough scrutiny, one always discovers that some game rules are obeyed to' (Lietti 1994: 185).

44 'Very early, in his or her family and social milieu, an infant must find the indispensable stimuli to develop communication in general and a given language in particular, and then to read texts afterwards. What kind of stimuli? These are not necessarily explicit ones. What goes without saying is essential and what surrounds any child: family habits, paternal patterns and attitudes' (Dalgalian 2000: 87).

45 'If mankind initiated linguistic communication in the modus of multilingualism, the latter was simultaneously handled in the modus of pejoration. Converting difference in subordination, considering the language of the Other as inferior (in most cases), even as a non-language (in the case of the Greeks), humans created the premise for a war between languages that religious or secular ideologies have fuelled afterwards. Although theoretical, this war developed in diverse directions [...] and was reactivated in a less platonic manner by governments. Language war seems to be linked with multilingualism itself: mankind hardly accepts differences' (Calvet 1999: 76). 
Citation: Georgelin, Hervé (2007) 'Illiteracy, ill-literacy and literacy among Western Armenians: En route from the Near East to the West, from the 1950s until today', European Journal of Turkish Studies, Thematic Issue $\mathrm{N}^{\circ} 6 \mid$ III-literate Knowledge, URL : http://www.ejts.org/document1313.html

To quote a passage, use paragraph (§)

neatly divided between the outside world and the familiar sphere. And this proved workable until Melanie became a teenager.

[40] At that time, Melanie stopped answering in Armenian. Her bilingualism became less comfortable ${ }^{46}$. The difference between the two languages, I mean by that first, the limited environment speaking Armenian, because there was at that time (in the seventies and early eighties) almost no Armenian community in Heidelberg and the surroundings, and second, the paucity of Armenian texts at home, while Germany is one of the countries publishing the most worldwide, disfavoured Armenian on a practical and symbolical level for the teenager. Armenian friends of her family remember her German accent in Armenian at that age. Needless to say, merciless remarks about her pronunciation by Armenian émigrés from the Near East were devastating for her self-image and her image of the Armenian group. The amazing part of the story is that this was not the last stage of her language development. She resumed speaking naturally at the end of her adolescence. Bilingualism is unstable but also flexible and perfectible. It is hard to maintain when conditions of practice are so obviously unequal between languages. The ill-literate knowledge of Armenian could not compete with the highly formalized use of German she had acquired ${ }^{47}$. During adolescence, the dominant symbolic frame was able to disqualify the second one that would have required much more tolerance, self-tolerance, and generosity impossible for a teenage girl to deliver.

[41] Melanie indeed came later to writing and reading in Armenian than in German. She was first trained by her mother at home to write letters to her relatives in Syria. The letter writing exercise was not a pleasant one. Classical orthography seemed to her an impossible aim. The motherdaughter relationship with latent conflicts had found an ideal context. But the daughter did not surrender to unpleasant feelings and kept learning. She really started to read Armenian books and literature at the age of seventeen, while she had been doing so at a much earlier age in German,

46 'Analyzing linguistic situations in the world shows that languages are deeply unequal. They are unequal from a statistical point of view: some are very widely spoken, others a little (which of course does not lessen their dignities). They are unequal from a social point of view: some are dominated, confined to gregarious functions, are never written nor used in education while others dominate and fulfil official, literary, cultural, international or emphasized communicative functions. They are unequal from the point of view of representations formulated about them. Some are considered as prestigious, others not, some are claimed by their speakers as identity languages, others are given up by the speakers themselves who do not transmit them any longer and prefer their children learn another one. Globalization by expanding communication networks increases inequalities between languages and reinforces the hypercentral one, English, and hypercentral languages to the prejudice of peripheral ones' (Calvet 2002: 102-103).

${ }^{47}$ A similar story is reported by Dalgalian (2000), involving French and Turkish, the latter being an oral language only, positively connoted, but remaining distant from any written and abstract practise, much to the author's frustration. 
Citation: Georgelin, Hervé (2007) 'Illiteracy, ill-literacy and literacy among Western Armenians: En route from the Near East to the West, from the 1950s until today', European Journal of Turkish Studies, Thematic Issue $\mathrm{N}^{\circ} 6 \mid$ III-literate Knowledge, URL : http://www.ejts.org/document1313.html

To quote a passage, use paragraph (§)

simultaneously with her German classmates attending good schools in the Old City of Heidelberg. She remembers having been most often the only 'non ethnic' -whatever that may mean- German in her class, even at her school. She thinks that helped her being 'integrated'. Her anonymous Christian name did not separate her from her classmates. In spite of her small size and her very dark hair, she could feel part of the group in her German environment in the seventies and early eighties, when expressions of racism were a complete taboo. She mentions, though, having been rarely teased by her classmates as a 'Fatma bacl', a multiple insult in her case as an Armenian. Actually, being Armenian was not much of an issue to talk about in her German environment. Still, she remembers as an exception a teacher who brought her a small souvenir from the Armenian St. James Monastery in Jerusalem, which bears a short inscription in Armenian, the name of the city: Epnzuuunzu. Religion teachers - religion being a compulsory topic in German schools at that time - would naively locate Armenia somewhere around Mount Ararat...

[42] But most peers would not pay much attention to Melanie's history and background. She was the ideal, invisible foreigner at school. Melanie is remembered by her teachers as a good pupil, especially in literary topics. Her essays in German were among the best in her class. She remembered though the distance between what she heard and experienced at home and what the norm of high culture [Hochkultur] was at school. Titles of books and names of writers already natural, or perceived as such, for children of the cultural bourgeoisie [Kulturbürgertum] had to be picked up and assimilated by Melanie on the spot, at school ${ }^{48}$. Melanie and her parents had a more respectful relationship with schoolteachers and with the school as an institution than some heirs of the local cultural establishment. In general, she felt closer to craftsmen's children caught in a similar acculturation process than to already socially established children. There was no consumer attitude towards the institution and nothing was taken for granted by them! No wonder they were rather popular among education professionals. Years later, the heirs may not have done much better in their

48 'The most favoured students don't only owe to their original milieu habits, trainings and attitudes that serve them directly in their tasks at school; they inherit too knowledge and know-how, tastes, 'good taste' whose payback at school, even if indirect, is nonetheless certain. The 'free' culture, which is the implicit precondition of success at university for certain disciplines, is dispatched in a very unequal way among students from diverse milieus, without the income differences accounting for the gaps observed. Cultural privileges are blatant when familiarity with art works is concerned, that only regular visits at theatres, museums and concert halls (which is not organised by the school system or only in a sporadic way) can provide. They are even more obvious in the case of works, generally the most modern ones, which are the less standard at school' (Bourdieu, Passeron 1985: 30-31). This apodictic analysis should be nuanced in a German context in the eighties. But its fundamental relevance is hard to deny. 
Citation: Georgelin, Hervé (2007) 'Illiteracy, ill-literacy and literacy among Western Armenians: En route from the Near East to the West, from the 1950s until today', European Journal of Turkish Studies, Thematic Issue $\mathrm{N}^{\circ} 6$ | III-literate Knowledge, URL : http://www.ejts.org/document1313.html

To quote a passage, use paragraph (§)

social life than she. They often proved less adaptable and adventurous than her. Some consider her living in Paris (about $550 \mathrm{~km}$ away, with excellent railway and highway connections) as the utmost extravagant thing.

[43] Melanie came to intensive literacy in Armenian, because by chance, an Armenian intellectual working in Strasbourg spent time in Heidelberg and happened to live in her building in the Old City. She remembers him as the only character able to change her perception of the Armenian language and to make it something different than the daily language, restricted to cooking and gossiping, that are respectable business from an anthropological point of view but that can be frustrating for a young person experiencing other stimulations outside the Armenian familiar world. She still feels gratitude towards this person, though the latter may not have intended to have such an impact. He helped her find a way to literature and some learned tradition inherited from the Istanbul Armenian intelligentsia and its heirs in the post-1915 Diaspora. Her own later migration to Paris meant contacts with a larger community -a complex word especially in a French context- and access to cultural resources undreamed of in Heidelberg, like robust language schools where she soon got involved as a teacher. She could study Armenian at the Paris-based Institute for Oriental Languages and Civilisations. At less than forty of age, Melanie is an uncommon case of bilingual Western Armenian with an experience of several stays in post-Soviet Armenia, where she happily is identified and accepted as a native speaker of Armenian and not a foreigner, a not so frequent occurrence in the case of Diaspora Armenians.

[44] The connection with English and French that Garabed and Siroun always had because of their connection to the American military base and their relatives in France and the US, made it obvious for their daughter Melanie that German was not the only Western language and that these two others were to be learned at any cost, which she did mostly at school. Today Melanie is fluent in both French and English. She is doing well in bringing up her children (G5 - K) in a multilingual environment.

\section{Conclusion}

[45] As a conclusion, inheriting the Ottoman Armenian illiteracy, ill-literacy, and also audiooral skills was synonymous with inheriting many social and human skills too and not just a social 
Citation: Georgelin, Hervé (2007) 'Illiteracy, ill-literacy and literacy among Western Armenians: En route from the Near East to the West, from the 1950s until today', European Journal of Turkish Studies, Thematic Issue $\mathrm{N}^{\circ} 6 \mid$ III-literate Knowledge, URL : http://www.ejts.org/document1313.html

To quote a passage, use paragraph (§)

burden. It was experienced by many of the post-1915 generations not only under the stigma of an inadequacy. Social performances in Aleppo or elsewhere were not directly linked with the people's literate proficiency. However, I have very rarely observed cynicism towards formal education among the people, with whom I have interacted. The limited access to the realm of books or newspapers implies or is accompanied by the necessity and pleasure to speak about topics, such as food or family affairs more than in other cultural settings. Such a milieu is very favourable to the development of high and diverse communicative linguistic skills. This family is my reference as far as working multilingualism is concerned, and certainly not the formal educational systems in Western Europe that are based on the refusal of experienced multilingualism ${ }^{49}$. Some individuals with very little formal education may prove outstanding practical linguists (Garabed, G3-K) and enjoy audio-oral knowledge out of reach for the letter-only educated. Garabed, for instance, knows the entire Armenian liturgy by heart, which he has learned by hearing only and can communicate in six languages. He is surpassed by his brother who had the chance to study in Italy. But still, in this domain, a tailor and an architect can compete.

[46] This case study shows that orality is not synonymous with social dysfunction, neither in the Near East nor in the West. But it is based on and also fosters tight and vivid human contacts, which contemporary urban life in the West (Paris or Orange County) discourages. Orality was a major trait of Western Armenian culture, understood as a part of the Ottoman whole. Non-Armenian population groups, also heirs of the imperial society, must share many of the characteristics described and interpreted above. I hope similarities between Western Armenians and the Turkish contemporary society are obvious for specialists of Turkey. The Western Armenian populations' migration to the West has affected deeply, though at a rather slow pace, the continuation of their cultural life. A feeling of loss is thus inherent to such an experience for most. In fact, this text may have been written just before generation five reorganises, redesigns, and further adapts its knowledge and social skills to local diverging contexts. Many changes are already observable: members of generation four living in the United States had access to university but are no more as flexible in their language as Near Easterners with much less formal education, because their

49 'Contrary to what certain people may think, language multiplicity is not specific to certain situations or continents. It is not the prerogative of the Third World, or of developing countries that one can easily imagine as torn between their 'dialects', their 'patois' and our 'languages', but it is a common condition even if its manifestations are different according to contexts' (Calvet 1999: 43). 
Citation: Georgelin, Hervé (2007) 'Illiteracy, ill-literacy and literacy among Western Armenians: En route from the Near East to the West, from the 1950s until today', European Journal of Turkish Studies, Thematic Issue $\mathrm{N}^{\circ} 6$ | III-literate Knowledge, URL : http://www.ejts.org/document1313.html

To quote a passage, use paragraph (§)

environment does not require nor support these skills. Generation five in the Near East is almost disconnected from Western cultural resources: no one speaks French (not to mention Italian) and English is minimal, equal to standard Syrian classroom English, while Arabic is more and more present as the language of reference. 
Citation: Georgelin, Hervé (2007) 'Illiteracy, ill-literacy and literacy among Western Armenians: En route from the Near East to the West, from the 1950s until today', European Journal of Turkish Studies, Thematic Issue $\mathrm{N}^{\circ} 6 \mid$ III-literate Knowledge, URL : http://www.ejts.org/document1313.html

To quote a passage, use paragraph (§)

\section{References}

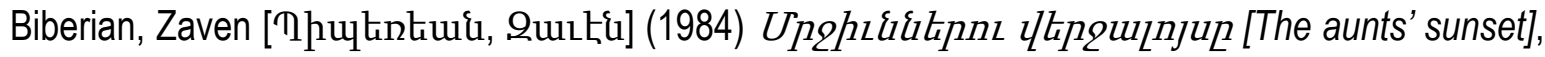
Istanbul, Zaven Biberian, Murat Ofset.

Bourdieu, Pierre; Passeron, Jean-Claude (1985 [1964]) Les héritiers, les étudiants et la culture, Paris, Les Éditions de Minuit.

Bruneau, Michel; Hassiotis, Ioannis; Hovanessian, Martine; Mouradian, Claire (eds.) (2007) Arméniens et Grecs en diaspora, approches comparatives. Actes du colloque, CNRS-EFA, Diasporas, 4-7 octobre 2001, Athens, EFA.

Calvet, Louis-Jean (1999 [1987]) La guerre des langues et les politiques linguistiques, Paris, Hachette Littératures (first ed. Payot).

Calvet, Louis-Jean (2002) Le marché aux langues, les effets linguistiques de la mondialisation, Paris, Plon.

Chaudron, Martine (1983) 'Des pratiques singulières aux phénomènes globaux, une pratique très quotidienne: faire la cuisine (un peu de l'histoire des femmes?)', in Fritsch, Philippe (ed), Le sens de l'ordinaire, Paris, Editions du CNRS, pp. 157-164.

Corbin, Alain (1998) Le Monde retrouvé de Louis-François Pinagot. Sur les traces d'un inconnu (1798-1876), Paris, Flammarion.

Corbin, Alain (2000) Historien du sensible. Entretiens avec Gilles Heuré, Paris, La Découverte.

Dahloul, Joëlle (1983) Le culte de la table dressée. Rites et traditions de la table juive algérienne, Paris, Éditions Métaillié.

Dalgalian, Gilbert (2000) Enfances plurilingues, témoignage pour une éducation bilingue et plurilingue, Paris, L'Harmattan.

Dufoix, Stéphane (2003) Les Diasporas, Paris, Presses Universitaires de France.

Dündar, Fuat (2006) L'ingénierie ethnique du Comité Union et Progrès : la turcisation de l'Anatolie (1913-1918), Paris, École des Hautes Études en Sciences Sociales [unpubl. PhD thesis].

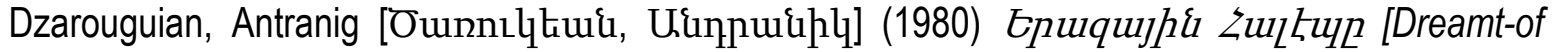
Aleppo], Aleppo, Bookshop Giliguia.

Giard, Luce (1994a [1980]) 'Arts de nourrir', in de Certeau, Michel; Giard, Luce; Mayol, Pierre, L'invention du quotidien, Paris, Gallimard, vol. 2, Habiter, cuisiner, pp. 214-239. [first ed. Union générale d'édition]

Giard, Luce (1994b [1980]) 'Le plat du jour', in Michel de Certeau, Luce Giard, Pierre Mayol, L'invention du quotidien, Paris, Gallimard, vol. 2, Habiter, cuisiner, pp. 240-279. [first ed. Union générale d'édition]

Guionnet, Christine; Neveu, Erik (2004) Féminins/Masculins, Paris, Armand Colin.

Hagège, Claude (1996) L'enfant aux deux langues, Paris, Odile Jacob. 
Citation: Georgelin, Hervé (2007) 'Illiteracy, ill-literacy and literacy among Western Armenians: En route from the Near East to the West, from the 1950s until today', European Journal of Turkish Studies, Thematic Issue $\mathrm{N}^{\circ} 6$ | III-literate Knowledge, URL : http://www.ejts.org/document1313.html

To quote a passage, use paragraph (§)

Hovanessian, Martine (2007 [1997]) Le lien communautaire. Trois générations d'Arméniens, Paris, L'Harmattan (first ed. Armand Colin).

Inglisian, P. Vahan (1929) Der Diener Gottes Mechitar von Sebaste, Stifter der Mechitaristen (der armenischen Benediktiner) und Kulturapostel des armenischen Volkes, Wien, Druck- und Verlag der Mechitharisten-Kongregation.

Kéhayan, Jean (2006) Mes papiers d'Anatolie, Luxemburg, L'Aube.

Kévorkian, Raymond H. (2007) Le Génocide des Arméniens, Paris, Odile Jacob.

Kieser, Hans-Lukas (2007) 'Ottoman Urfa and its Western Missionaries', in A Quest for Belonging, Anatolia beyond Empire and Nation (19th-21st centuries), Istanbul, The Isis Press, pp. 67-113.

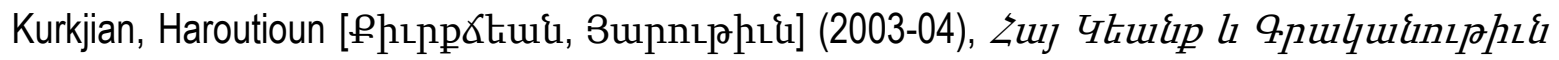
[Armenian Life and Literature], Athens, Kurkjian, vol. 1 \& 2.

Lietti, Anna (1994 [1982]) Pour une éducation bilingue, Paris, Payot, Petite Bibliothèque.

Lynch, Kevin (1960) The Image of he City, Cambridge, Mass./London, The M.I.T. Press.

Mandel, Maud S. (2003) In the Aftermath of Genocide: Armenians and Jews in Twentieth-Century France, Durham, Duke University Press.

Rowe, Victoria (2003) A History of Armenian Women's Writing: 1880-1922, London, Cambridge Scholar's Press.

Schroer, Markus (2006) Räume, Orte, Grenzen, Auf dem Weg zu einer Soziologie des Raums, Frankfurt am Main, Suhrkamp.

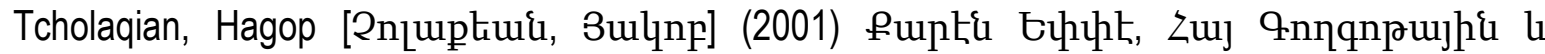
ltipurduntunhi htun [Karen Jeppe, with the Armenian Golgotha and Rebirth], Aleppo, Dbaran Arveleq.

Thompson, Paul (2000 [1978]) Voices of the Past, Oral History, Oxford, Oxford University Press.

Todd, Emmanuel (1994) Le destin des immigrés, Paris, Seuil. 